International Journal of Life Sciences
Available online at http://sciencescholar.us/journal/index.php/ijls
Vol. 3 No. 2, August 2019, pages: $52 \sim 58$
e-ISSN: 2550-6986, p-ISSN: 2550-6994
https://doi.org/10.29332/ijls.v3n2.321

\title{
Short Rest Application Reduce Workload and Musculoskeletal Complaints Public Transportation Driver
}

\author{
(C) CrossMark
}

I Ketut Sutapa ${ }^{\text {a }}$

Article history: Received 27 December 2018, Accepted: 30 April 2019, Published: 26 August 2019

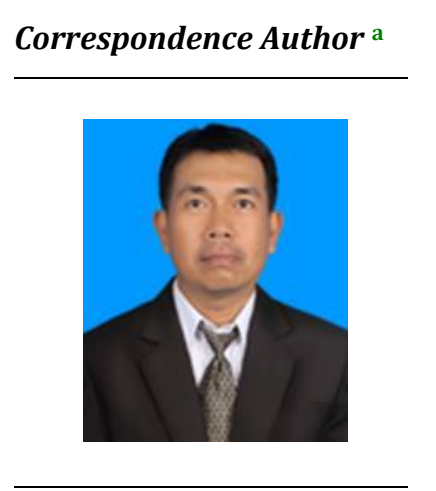

Keywords

comfortable;

ergonomics;

short rest;

weight;

workloads;

\begin{abstract}
It was needed an ergonomic work system to increase productivity for the vehicle driver work systems involves a lot of physical activity. Regarding preliminary observations, it showed the work system that was implemented still has shortcomings, unlike the work organization. Therefore, it needs to be prioritized to be improved. It becomes healthier, safer, more comfortable, and more productive. The driver's work system improvement was carried out with an ergonomics approach. The study design used was the same subject design with ten people sample for each group. The study focused on the application of short rest with indicators of workload and musculoskeletal excitability before and after the short rest application. Based on the results of research and discussion can be concluded. The short rest application reduced the workload of vehicle drivers $28 \%$ from the category of moderate workloads to being moderate and reducing musculoskeletal complaints $42.21 \%$.
\end{abstract}

e-ISSN: 2550-6986, p-ISSN: 2550-6994C Copyright 2019. The Author. SS Journals Published by Universidad Técnica de Manabí. This is an open-access article under the CC BY-SA 4.0 license (https://creativecommons.org/licenses/by-sa/4.0/) All rights reserved.

\section{Contents}

Abstract. 52

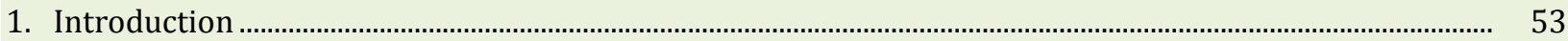

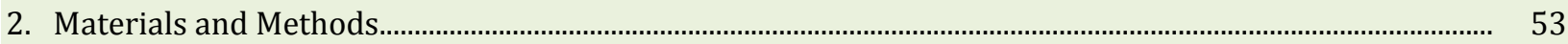

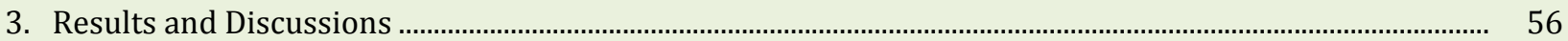

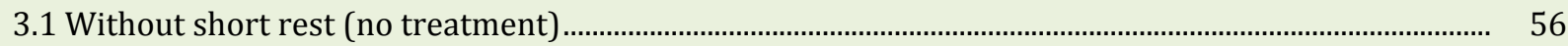

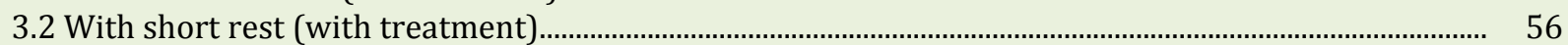

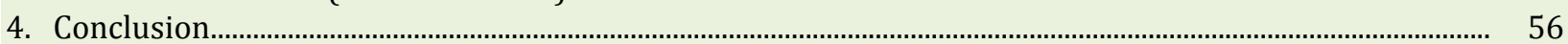

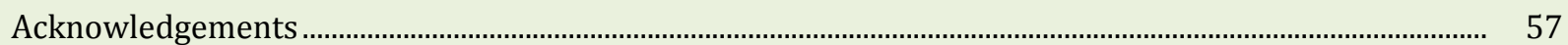

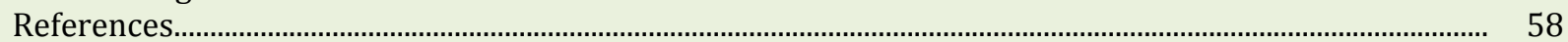

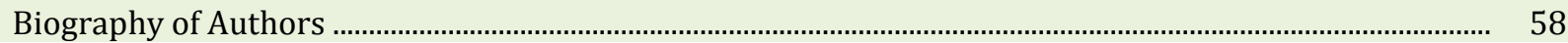

a Politeknik Negeri Bali, Badung, Indonesia 


\section{Introduction}

Work tool is one component must be considered regarded as to efforts to increase work productivity. The increase in productivity will be achieved if all components working system is ergonomically designed (Manuaba, 2003). The working system on the crybaby industry in order to achieve a sustainable work system needs a thorough study with a total ergonomics approach. The total ergonomics approach encourages active participation for all parties to identify problems to be fixed and determine the technology to be used. The technology used on working systems design refers to appropriate technology. It is comprehensively reviewed through six criteria, namely technically, economically, ergonomically, socio-culturally, saving energy and not damaging the environment (Manuaba, 2004). The problems exist are solved on SHIP approach (systemic, holistic, interdisciplinary, participatory) in order to create a conducive mechanism of work and obtain quality products (Manuaba, 2005). The ergonomics aspect, several working conditions/systems have not followed the ergonomic rules on making process included: (a) non-physiological work attitude, therefore, it is less comfortable. The workload is quite heavy. There are often musculoskeletal complaints. This condition if it is done repeatedly can increase the risk of cumulative trauma disorders (Manuaba, 2003b; Budiyanto et al., 2019); (b) the use of considerable muscle power; (c) the layout of work system facilities is less ergonomic. Workers who work like this condition have the potential to experience musculoskeletal disorders, fatigue, and the risk of work accidents.

The organizational improvement is conducted to overcome the problems, applying short rest to reduce the workload and musculoskeletal complaints through a participatory approach. It is expected to create conditions and a healthy, safe, comfortable and efficient work environment (Manuaba, 1996; Sutapa et al., 2017). Consequently, it can reduce the incidence of fatigue, complaints of the musculoskeletal system, loss of work, and improve work efficiency.

\section{Materials and Methods}

\section{Research Design}

The present research was used in the same subject design. It was serial, wherein all samples control treatment 0 , also receive corrective treatment (treatment 1) in different time periods. This design can be drawn in the following Figure 1:

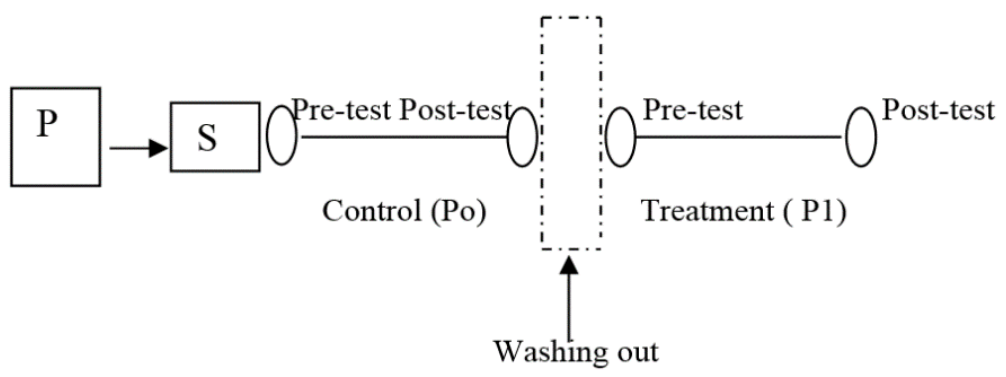

Figure 1. Research Design

\section{Description:}
P : vehicle driver
S : vehicle driver
P0 : control group, drivers who work without short rest accompanied by without treatment
P1 : treatment group 1, the driver is treated with short rest accompanied by with treatment washing out to eliminate the effects of the previous treatment.
Pre test : initial fatigue score

Sutapa, I. K. (2019). Short rest application reduce workload and musculoskeletal complaints public transportation driver. International Journal of Life Sciences, 3(2), 52-58. https://doi.org/10.29332/ijls.v3n2.321 
Post test : final fatigue score.

\section{Analysis Design}

Normality test and analysis of differences in treatment effects. The normality of the pre and post samples were tested with the Kolmogorov-Smirnov one-sample test at the level of confidence $\alpha=0.05$. Analysis of differences in treatment effects is to analyze the difference in pulse before and after WO and post pulse before and after WO, the Paired Samples T-test was used at the confidence level $\alpha=0.05$. Hypothesis:

Ho: $\mu \mathrm{k} 1=\mu \mathrm{k} 2$ (There is no difference in prepulse before and after WO)

$\mathrm{H} 1: \mu \mathrm{k} 1 \neq \mu \mathrm{k} 2$ (There is a difference in prepulse and before WO)

Ho: $\mu \mathrm{p} 1=\mu \mathrm{p} 2$ (There is no difference in post pulse before and after WO)

H1: $\mu \mathrm{p} 1 \neq \mu \mathrm{p} 2$ (There are differences in post pulse before and after WO

Independent Variable: Treatment P1 and P0. The dependent variable is workload (working pulse; work pulse) and Skeletal Muscle Disorders. Control variable P0. The population is ten men vehicles driver with the following variations. (a) age: 35-40 years old, (b) education: high school, (c) weight: 52-68 kg, and (d) work experience of more than 1 year.

The technique of collecting the data namely primary data collection. (1) Observation is conducted to observe working conditions. It is included the demands of the task of the work organization and the work environment. (2) Indication of physical workload is obtained through pulse calculation to ten beat method. It is carried out before working, palpation technique on the radial pulse. The measuring instrument used is the stopwatch brand Hewins made in Switzerland. (3) Indication of musculoskeletal complaints level is obtained through the filling of the Nordic Body Map questionnaire. (4) Data on age, height, weight, work experience and general complaints data obtained through interviews. (5) The camera is used to document work attitudes when workers carry out their activities. The study was conducted from $09.00 \mathrm{am}$ to $12.00 \mathrm{pm}, 02.00 \mathrm{pm}$ to $04.00 \mathrm{pm}$ hours with measurement activities.

1) Before Work

a) Measurement of resting pulse rate,

b) Measurement of work environment temperature and relative humidity.

2) At Working

a) Measurement of the pulse during work in every hour,

b) Measurement of air temperature and humidity in every hour

3) After Work

a) Measurement of work pulse

b) Completion of musculoskeletal complaints questionnaires

c) Measurement of air temperature and humidity

Data Analysis

Measurement results are in the form of the resting pulse ( $\left.\mathrm{DN}_{\text {rest }}\right)$, working pulse $\left(\mathrm{DN}_{\text {work }}\right)$, vehicle drivers.

Table 1

Pre and post pulse distribution of Po and P1 groups

\begin{tabular}{lllll}
\hline \multicolumn{3}{c}{ Pulse } \\
\hline No & Pre Klp. P0 & Post KLp. P0 & Pre Klp. P1 & Post Klp. P1 \\
\hline 1 & 76 & 125 & 70 & 105 \\
2 & 70 & 120 & 80 & 100 \\
3 & 72 & 120 & 76 & 100 \\
4 & 72 & 115 & 80 & 105 \\
\hline
\end{tabular}




\begin{tabular}{lllll}
\hline 5 & 72 & 120 & 70 & 110 \\
6 & 78 & 120 & 75 & 95 \\
7 & 70 & 130 & 75 & 98 \\
8 & 72 & 120 & 70 & 110 \\
9 & 75 & 120 & 70 & 100 \\
10 & 75 & 125 & 72 & 95 \\
MEAN & 73.2000 & 121.5000 & 73.8000 & 101.8000 \\
SD & 2.6583 & 4.1164 & 4.0222 & 5.4934 \\
\hline
\end{tabular}

Normality Test

The results of the normality test with one sample Kolmogorov-Smirnov t-test for pre and post pulses in groups $\mathrm{K}$ and $\mathrm{P}$ are presented in Table 2.

Table 2

Normality test results using K-S test

\begin{tabular}{llccccc}
\hline No & Variable & $\mathrm{N}$ & Average & $\begin{array}{c}\text { Std. } \\
\text { Deviation }\end{array}$ & $\mathrm{Z}$ & $\mathrm{P}$ \\
\hline 1 & $\begin{array}{l}\text { Pre pulse } \\
\text { before WO (P0) }\end{array}$ & 10 & 73.2000 & 2.6583 & 0.867 & 0.440 \\
2 & $\begin{array}{l}\text { Post pulses } \\
\text { before WO (P0) }\end{array}$ & 10 & 121.5000 & 4.1164 & 1.082 & 0.192 \\
3 & $\begin{array}{l}\text { Pre pulse after } \\
\text { WO }\end{array}$ & 10 & 73.8000 & 4.0222 & 0.720 & 0.678 \\
4 & $\begin{array}{l}\text { Post pulses } \\
\text { after WO }\end{array}$ & 10 & 101.8000 & 5.4934 & 0.722 & 0.674 \\
\hline
\end{tabular}

Table 2 shows the mean pre pulse on Po group before WO is 73.2000 with a standard deviation is 2.6583 . The post pulse rate on Po group before WO increased an average is 121.5000 with a standard deviation is 4.1164. Whereas, in P1 group after WO, it was seen that the mean pulse rate is 73.8000 with a standard deviation is 4.0222. Likewise, the post pulse in P1 group after WO decreased the mean pulse rate is 101.8000 with a standard deviation is 5.28563 .

The lowest mean pulse rate is seen on $\mathrm{P} 1$ group after WO is held at 101.8000. regarding the normality test results with the one-sample Kolmogorov-Smirnov t-test at the confidence level $\alpha=0.05$. It is found that $P$ and post values on Po and P1 groups are greater $0.05(\mathrm{p}>0.05)$ indicates that all variables are normally distributed.

\section{Analysis of Treatment Effects Difference}

Difference test results with paired sample t-test are presented in Table 3.

Table 3

Different test results for treatment effects

\begin{tabular}{lllll}
\hline Treatment & Average & $\begin{array}{l}\text { Average } \\
\text { difference }\end{array}$ & $\mathrm{t}$ & $\mathrm{P}$ \\
\hline P0 & 73.2000 & -48.3000 & -30.746 & 0.000 \\
P1 & 121.5000 & & -11.389 & 0.000 \\
\hline
\end{tabular}

Sutapa, I. K. (2019). Short rest application reduce workload and musculoskeletal complaints public transportation driver. International Journal of Life Sciences, 3(2), 52-58. https://doi.org/10.29332/ijls.v3n2.321 
101.8000

Table 3 shows the treatment effect with paired samples t-test on confidence level $\alpha=0.05$. It is obtained the results $p$-value for pulse rate variable before and after WO is smaller than $0.05(\mathrm{p}<0.05)$ and $\mathrm{p}$-value for the post pulse variable before and after WO smaller than $0.05(\mathrm{p}<0.05)$. Thus, there is a difference in workers pulse without rest with and without short rest. A decrease in pulse rate after a short rest accompanied.

\section{Results and Discussions}

\subsection{Without short rest (no treatment)}

Vehicle driver workload includes the category of medium workload. It is the mean working pulse 121.50 $\mathrm{dpm}( \pm 4.1164)$ and the average resting pulse rate was $73.20 \mathrm{dpm}( \pm 2.6583)$. therefore, there is an increase in pulse rate due to work $66 \%$. The attitude of the work is to bend slightly both on standing position and when squatting. Musculoskeletal complaints after work increased is $73.05 \%$ from the mean score before work 16.70 $( \pm 4.30)$ to $28.90( \pm 3.31)$.

Adiputra (1998), stated that workload based on factors. Due to it can be divided into two, namely: (a) external workload (stressor) due to external factors including task, organization and environment and (b) internal workload namely workload due to individual factors. They are somatic, including gender, age, body size, health conditions, and nutritional status, and psychological factors include motivation, perception, desires, and others. The pulse frequency during activities is used as a basis for assessing physical workload due to the changes in the mean pulse during activity correlate linearly with oxygen requirements (Rodahl, 1995).

\section{Work organization}

Working time eight hours per day including lunch break during the week except for holidays/other holidays or if there are no orders. Business hours start at 09.00 am to $05.00 \mathrm{pm}$. Rest hours start at $12.00 \mathrm{pm}$ to $13.00 \mathrm{pm}$. There is no additional rest or additional calorie intake in between work. A person works for 6-8 hours a day and the remaining 18-16 hours is used for rest/sleep and time for family.

Working continuously without additional rest and calorie intake on working sidelines will certainly result in the accumulation of fatigue which in turn increases workload. It is marked an increase on working pulse and musculoskeletal complaints. Nala (1994), stated that unnatural work attitudes cause static (isometric) muscle contractions in a large number of human body's muscular systems and static muscle contractions can result: (a) higher energy or energy required in the same effort (b) the pulse rises higher, (c) feels tired quickly and (d) after work, the muscles need a longer recovery time.

\subsection{With short rest (with treatment)}

The workload on vehicle driver decreased with the mean pulse work $101.80 \mathrm{dpm}( \pm 5.50)$ and the average resting pulse rate was $73.80 \mathrm{dpm}( \pm 4.02)$. therefore, there is a decrease in working pulse $38 \%$. Resting pulses before and after treatment were not significantly different ( $p>0.05)$. After treatment, there was a significant decrease in work pulse $(\mathrm{p}<0.05)$ or $28 \%$ from the category of moderate workload. There was a significant decrease after treatment in musculoskeletal complaints $(\mathrm{p}<0.05)$ or $42.21 \%$.

\section{Conclusion}

The following conclusions can be made.

1) Resting pulse rate before and after treatment is not significantly different ( $p>0.05)$. After treatment, there was a significant decrease in work pulse $(\mathrm{p}<0.05$;) or $28 \%$ medium workload category.

2) After treatment, there was a significant decrease in Musculoskeletal complaints $(p<0.05)$ by $42.21 \%$. 
Acknowledgments

The authors would like to thank the editorial team of IJLS for their valuable time, support, and advice in completing the present paper.

Sutapa, I. K. (2019). Short rest application reduce workload and musculoskeletal complaints public transportation driver. International Journal of Life Sciences, 3(2), 52-58. https://doi.org/10.29332/ijls.v3n2.321 


\section{References}

Adiputra, N. (1998). Metodologi Ergonomi. Denpasar: Program Studi Ergonomi Fisiologi Kerja-Program Pascasarjana Universitas Udayana, 11-12.

Budiyanto, T., Adiputra, N., Sutjana, I. D. P., \& Tirtayasa, K. (2019). Application of RULA analysis on work posture improvement to reduce workers' fatigue and musculoskeletal complaints and to accelerate processing time of wok molding. International research journal of engineering, IT \& scientific research, 5(4), 8-15. https://doi.org/10.21744/irjeis.v5n4.648

Manuaba, A. (2003). Holistic design is a must to attain sustainable product. Jurnal Ergonomi Indonesia, 4(212), 45-49.

Manuaba, A. (2003, September). Total ergonomic approach to enhance and harmonize the development of agriculture, tourism, and small scale industry, with special reference to Bali. In National Congress and Seminar of the Indonesian Ergonomics Association (PEI) (Vol. 13).

Manuaba, A. (2004, October). Kontribusi Ergonomi dalam Pembangunan, dengan Acuan Khusus Bali. In 2nd National Seminar on Ergonomics, UGM, Yogyakarta (Vol. 9).

Manuaba, I. B. A. (2005). Total ergonomics enhancing productivity, product quality and customer satisfaction. Indonesian Journal of Ergonomics, 6, 1-6.

Nala, N. (1994). Penerapan Teknologi Tepat Guna di Pedesaan. Denpasar: Lembaga Pengabdian Kepada Masyarakat Universitas Udayana.

Rodahl, M., Höök, F., Krozer, A., Brzezinski, P., \& Kasemo, B. (1995). Quartz crystal microbalance setup for frequency and Q-factor measurements in gaseous and liquid environments. Review of Scientific Instruments, 66(7), 3924-3930.

Sutapa, I. K., Sutapa, I. N., \& Susila, I. N. D. (2017). Implementation of active rest in participatory ergonomics decrease workload and women musculoskeletal complaints of parking in mall Ramayana Denpasar. International journal of life sciences, 1(2), 48-54. https://doi.org/10.21744/ijls.v1i2.42

\section{Biography of Author}

\begin{tabular}{|l|l|}
\hline I Ketut Sutapa, S.ST, MT. was born on June 26th, 1967. He is a senior lecturer at Bali \\
State Polytechnic, Bukit Jimbaran, Kuta, Badung, Bali. He is recently going to finish \\
his Doctorate Degree on July 20th, 2016 at University of Udayana. He researches \\
interest in transportation and engineering as well his papers have been published \\
at many publishers especially in International Journals. \\
Email: ketutsutapa@pnb.ac.id
\end{tabular}

